Various objects have been met with, arms and armonr, vases, ceramics, \&c, and in one tomb, it is said, a warrior has been discovered fully equipped, and in such preservation that the beard was intact. M. Millet recalls the fact that in the invasion of Gaul by Julius Cresar, there was a camp of great importance on the plateau above Gouvieux, some ten kilom. from the place of excavation, and on the route from Chantilly to Persan; the place is still known as Cæsar's Camp. Numerous battles took place in the valley of the Oise, as is attested by the medals, coins, \&c., often found by farmers in that region. One of these combats was so murderous that the place where it was probably fought bears the name of Pres de tuerie; it is at the foot of Beaumont-sur-Oise. The excavations referred to are still in progress, and will doubtless be watched with interest.

THE anntal general meeting of the Manchester Field Naturalists' and Archæologists' Society was held on the 21st inst., Mr. John Angell, F.C.S., vice-president, in the chair. Mr. Alfred Griffiths, secretary, read the report for the past year, which stated that 1878 had been devoted to the aims of the Society, with an average success. Mr. Angell gave an address on the science of 1878 , in which he reviewed, in an intelligent and appreciative manner, some of the main scientific points of interest during the past year.

THe Geological "Landesanstalt" and Mining Academy at Berlin has recently been considerably enlarged. The institution has moved into new buildings which have just been completed, and which contain a rich collection of maps, minerals, roclis, fossils, \&c., besides a large library and laboratories for geologica!, analytical, metallurgical, and technological work.

THE existence of a subterranean oak forest in the neighbourhood of Rotenburg, Prussia, was proved last summer by the State geologist of that district, Dr. Moesta, of Marburg. The investigations of this gentleman bave shown that in the plain of the Fulda valley an oak forest lies buried at a depth of some two or three metres, the origin of which dates back to the tertiary period perhaps, and of which the river Fulda has laid bare many traces by erosion. The wood of the oak trees thus brought to light has by the long action of the water been stained quite black, but still retains considerable firmness. The size of the trees is very considerable, and it remains yet to be proved whether they belong to the same family as the oaks now existing.

A GERMAN paper states that a descendant of the great Copernicus is living now at a small town of Posen, exercising the calling of shoemaker. It is known that Copernicus was a canon of the chapter of Frauenburg, and must be supposed to have died without leaving any issue. It has been said that his true son was Kepler, and that in his turn Kepler was the scien. tific father of Newton.

Tyz additions to the Zoological Society's Gardens during the past week include an Entellus Monkey (Semnopithecus entellus) from India, presented by Mr. J. Mills, R.H.A.; two Prairie Marmots (Cynomy's ludovicianus) from North America, presented by Miss Agneta B. Dykes; four Common Gulls (Laras cana), a Common Widgeon (Maraca penelope), four Grey Plovers (Squatareola helvetica), three Knots (Tringa canutus), a Dunlin (Tringa cinclus), European, presented by Mr. F. Cresswell ; a Blue and Yellow Macaw (Ara ararauna) from South America, presented by F. G. J. Lillingston, Lieut. R.N.; two Coypu Rats (Myopolamus coypu), a Brown Coati (Nasua nasica), a Chilian Sea Eagle (Geranoaëtus melanoleucus), a Dinca Finch (Dinca grisea), two Saira Tanagers (Pyranga saira), two Dark Green Maize Eaters (Pseudoleistes virescens), two Blue-bearded Jays (Cyanocorax cyanopogon) from Buenos Ayres, two Garden's Night Herons (Nycticorax gardenzi), an Ariel Toucan (Ram- phastos arien), a White-bellied Thrush (Turdus albiventris) from Bahia, a Great Frigate Bird (Fregata aquila) from Pernambuco, a Brazilian Biue Grosbeak (Guiraca cyanea) from Mexico, purchased; two Cuming's Octodons (Octodon cumingi) from Chili, deposited.

\section{EARLY EXPERIMENTS ON THE CONDUC TION OF ELECTRICITY BY SUBMARINE WIRES FOR ILLUMINATING DISTANT PLACES AND PROPOSALS FOR THE DIVI- SION OF THE LIGHT INTO SEPARATE LIGHTS}

I DO not profess to be acqnainted with the means which have been recently employed for conveying electricity to illuminate places at a distance or for sut-dividinu the electric light, nor is it with the slightest wish to derogate from the merit of recent inventors that I now submit a few facts as to earlier labours in the same field which may perhaps be interesting to the readers of NATURE.

So far as I know, the first suggestion of communicating electricity for lighting purposes to distant places was in the fourth volume of the Trans. Roy. Scott. Soc. of Arts, vol. iv., 1854 . In describing the apparent light on a sunken reef in the sea a the entrance of Stornoway Loch, which was lighted in 1851, stated that "it occurred to me that in some cases gas-pipe might be laid or even sibmarine zires, so as to illuminate a lantern placel on a beacon or buoy." I did not, however, consider it safe, "at least in the present state of our knowledge," to adopt either of the e plans; but gave the preference to an apparent light illuminated by a beam of rays projecied from a lens placed on the shore at a distance of 530 feet from the sun' rock, which plan has been in use : ince 1851 .

In 1852, and therefore not long after the erection of the Stornoway light, Admiral Sheringham used electricity for producing heat for the purpose of inniting gas at a buoy.

My friend, Mr. Alan Brebner, C.E., suggested, as referred to in Messrs. Stevenson's Report on the electric liglit in 1865 , that the lighthouses of Scutland might be illwuinated from one great central station.

In I 865 I made experiments for the Commissioners of Northern Lighthouses with the sanction of the Board of Trade, on lighting beacons by submarine wires, and on the suggestion of my friend Prof. Swan, increased the flashes by combining a Leyden jar with an induction coil. On January 13,1866 , I communicated to the Secretary of the Roy. Scott. Society of Arts that the induction spark placed in the foctis of lighthouse apparatus gave in all respects satisfactory results at the distance of haif a mile which, owing to intervening objects, was the greatest distance from which it could be seen. The primary current was also liept for a week passing continuously night and day, through 800 feet of wire without any sensible waste of the platinum electrodes. I next attempted to pass the current through a cabie under the sea, fut without succe:s, when Messrs. Sievenson applied to Dr. Siemens for his assistance in the matter, and he recommended an electro-magnet on the beacon with a contact lever actuated by the annature of the electro-magnet in the manner of a Neft's hammer. The luminous effect was increased by the deflagration of mercury. This plan, as tried at Granton Harbour, was quite :ucce-sful; but the products of combustion viere deposited on the optical apparatus, and some mechanical difficulties interfered with its continuous working.

Being thus thrown back on the old plan of the induction spark, $I$ was enabled to overcome the difficulties by the following expedients :-Mr. Brebner suggested plucing the induction coils with condensers close to the optical apparatus on the beacon and the battery and contact breaker on the shore, so as to pass only the primary current through the cable. Mr. Hart, electrician, also designed an improved break for the purpose, and Prof. Tait recommended the enlargement of the earth terminals. By these arrangements the current was passed successfully under the sea. The experiment was repeated at Granton, at the request of the Trinity Hou e of London, in presence of Captains Fenwick and Nisbet, and Mr. Duuglass, the erigineer, accompanied by $M r$. Farrer and Mr. Shaw Lefevre of the Board of Trade. 1 The distance between the battery and break on Granton Pier and the induction coils and optical apparatus on Newbaven Pier is

1 " Propisais for the Illumination of Beacons and Bucys," by T. Stevenson, p. is. (Edirburgh: A, and C. Elack, 187a) 
upwards of half a mile, but the actual length of wire which was submerged, and throush which the current passed, was upwards of a mile. The spark was about $\frac{1}{4}$ inch in length, bluish white in colour, and very striking and interesting in effect. It was placed in the focus of a holophotalised parabolic reflector.

At the same time in order to ascertain if by means of a single battery under the charge of one keeper a succesion of flashes could be produced and a string of isoltzted dangers illuminated, the light was sub-divided first into two separate. flashes and afterwards into six different sparks. The separate lights were quite satisfactory, though they were not as might have been ex. pected of the same power as the original single one. But as the separate sparks were very close to each other this cannot, I presume, be held to be a proper sub-division of the light.

In I857, at the British Association at Dundee, I suggested that the "effect of the light might be also increased without using additional cells if the same current could be again utilised so as to generate a second spark in the sane focu. This was proposed to be done by 'using additional coils' for the same focus or separate sparks in the foci of separate reflectors. ${ }^{1}$ I also added that the "time is perhaps not far distant when the beacons and buoys in such a navigation as the entrance to liverpool may be lit up by submarine conduction from a central station on either shore, while the whole management may bo trusted to the charge of one or two light-keepers." a

I may add that similar trials were made with Wilde's electromagnetic machine, which gave a light of much greater volume and nower. The electrodes employed in all the :e experiments were made of platinum, but several other metals were experimented with, and of all that were tried bismuth was found to give the brightest light. ${ }^{3}$

A committee of the Seattish Society of Arts, consisting of Dr. Ferguson, convener, Dr. Lees, and the late Dr. Strethill Wright reported in the following terms: ${ }^{56}$ The peculiar character of the light, which is flickering, though continuous, is well marked and would be easily understood. So far as Mr. Stevenson's experiments $\mathrm{g}$, , they seem to prove the practicability of his pro. posal and your committee do not anticipate any serious obstacle bo its realisation."

TMOMAS STEVENSON

Edinburgh

\section{UNDERGROUND TERPERATURE}

D K. STAPFF has continued his observations of the temperature in the St. Gothard Tunnel, and has contributed to the S rriss Natural History Society a paper ${ }^{5}$ of fifty-six quarto pares, embodying the results.

The following is his description ( $p$ p. 26, 27), of the mode of observing the temperature of the rocks in the tunnel :-

"The exact determination of the temperature of the rocks in the tunnel formerly occasioned a notable expenditure of time and money. At first thermometers about a metre long (made by $\mathrm{J}$. Goldschmid, of Zurich) were employed for this purpose; their tuhes being cemented into a wooden cylinder, so that only the bulb (surrounded by a perforated steel cap) projected below, and the scale (extending from $15^{\circ}$ to $30^{\circ} \mathrm{C}$.) atove. Tallow was poured roind the wooden cylinder, and the whole thermometer poured round into a bore-hole a metre deep, so that only the scale projected, from which readings were taken from time to time until the temperature became constant. The final reading had to be corrected not only for rise of zero but also for the temperature of the quicksilver in the thermometer tube which extends from the opening to the bottom of the bore-hole. Another very notable correciion was required for the more or less oblique position of the thermometer; for the hydrostatic pres sure of the quicksilver presses out the glass bulb so far that without change of temperature the long thermometer reads from $0^{\circ} 4$ out coange of the vertical than in the horizontal position.

" ${ }^{\circ}$ "O less in the vertical than in the hout from three to ten days, the reading of a thermometer luted into a bore-hole ceased to aiter.

"Separare trials with thermometers of similar construction, but different length, showed, moreover, that, after months, the temperature of the rock at about a metre deep was still un. - British Association Reports, 5867 . 2 Ibid.

3 "Proposals $f x$ the Illumination of Beacons and Buoys," pp. I4-x5. (Edinburgh: A. and C. Black.)

4 Eleventh Report of the British Association Underground Temperature Committee, by Prof. Everett.

5 "Studien über die Wărmevertheilung im Gotthard," I Theil. "Der schweirerion naturforschenden Gesellschaft zu ihrer sechzigsten Jahresversammlung in Bex gev:dmet," von F. M. Stapff. Bern, 1877 . changed. This is obviously owing to the smail difference of temperature between the rock and the surrounding air.

"From the observations at No. 8 and No. 15, in Table III., it is seen that the temperature at the bottom of the bore-hole was sometimes a little lower and sometimes a little hisher thain nearer its mouth.

"This mode of observing gave correct results, but was laborious and costly, not only on account of the necessity of making special bore-holes for the purpose, but because almost every experiment cost a thermometer. The projecting end was often maliciously broken off, and on account of the swelling of the wooden case it almost never happened that at the end of an experiment a thermometer was drawn out again uninjutred.

"Hermann and Pfister remedied this latter evil by surrounding the thermometer-tube from the bulb to the scale, with a glas case, and this with a steel jacket. This arrangement, however, involves not only conduction through the steel, but also continual interchange of heat by currents of air in the glass case, from the mouth to the bottom of the hole. For these reasons the obser vations made with these thermometers could not be employed without intricate corrections.

"Later I tried a Thomson's maximum thermometer, ${ }^{1}$ kindly placed at my disposal by Prof. Everett, which (after previous strong cooling) was left for several days at the bottom of the bore-hole, closed air-tight. The results agreed with those obtained by other methods; but who can guarantee that the higher temperature prevailing in a newly-bored hole is always just so much depressed by the cold mass of the thermometer and its copper case, that the rock-temperature alone determines the fnal indication of the maximum thermometer?

"This consideration induced me to employ for rock-temperature observations (and they also serve for air and water observa tions), the above-mentioned short thermometers with insulated bulbs, the first of which Prof. Everett caused to be made by Negretti and Zambra for this express purpose. These thermometers, inclosed in a metal box provided with a handle, are thrust to the bottom of the bore-hole, which is at least a metre deep. To the handle is fastened a strong cord reaching to the mouth of the hole, by which it can be drawn out again at the end of the trial. The bore-hole, from the thermometer to the mouth, is stopped with greased rag or other similar material, as zir-tight as possible. After two or three days, the thermometers have usually assumed the temperature of the surrounding rock, that is to say, their reading has ceased to alter. The insulation of the quicksilver prevents alterations during the drawing-out and reading of the thermometer. The correctness of the result is in no way prejudiced by sediment from the boring which may yet remain in the hole. The pouring in of some water may even be useful in accelerating the experiment. Wet bore-holes with standing-water are, however, to be avoided, because rocktemperature and water-temperature are not identical.

"In the manner last described, at every available opportunity, that is to say, when the work of the tunnel is from any cause compelled to cease for a few days, rock-temperature observations are now instituted in bore-holes ready to our hand. The observations are simple, give exact results if taken with proper precaution and sufficient duration of the experiment, and cause no further expense, since the thermometers, being sunk in the rock, are secured against wanton inj'ry, and there are always bore-holes available."

Dr. Stapff further states by letter that the two original thermometers supplied by Negretti and Zambra having been broken, he has had others made, in which he has introduced the improvement of hermetically sealing the outer glass case, instead of closing it with a waxed cork, which gradually armitted moisture.

In the Report for 1876 an accotint was given of the observations of Herr Dunker in a bore about 4,000 feet deep at Sperenberg, and allusion was made to the undue weight which had been attached by some writers to the empirical formula in which Herr Dunker sums up bis observations; a formula which indicates a retarded rate of increase, and, if extended to greater depths, leads to the conclusion that the temperature reaches its maximum at the depth of about a mile.

A discussion has been carried on in Germany on this subject," $x y$ was one of the protected Negretti maximum thermometers constructed for the Committee.

${ }^{2}$ See papers by Mohr, Heinrich (two papers), Dunker, and Hottentoth, in the "Neues Jahrbueh" for 1875 , x876, and 1877 ; by Brauns, in the "Zeitschrift für die gesammtea Naturwissenschafien," I874, P. 483; and by Hann, in the "Zeitschrift der österreichischen" Gesellschaft fur Meteorologie," ${ }_{1878} 8$, p. $x 7$. 